\title{
Pengaruh Model Pembelajaran Problem Based Learning (PBL) Terhadap Kemampuan Komunikasi Matematik Siswa SMP
}

\author{
(Effect Of Problem Based Learning (PBL) Learning Model On The Ability Of Mathematic \\ Communication Students SMP)
}

\author{
Hafely $^{1}$, Anwar Bey ${ }^{2}$, La Ode Ahmad Jazuli ${ }^{2}$, Nana Sumarna ${ }^{3}$ \\ ${ }^{1}$ Alumnus Jurusan Pendidikan Matematika FKIP Universitas Halu Oleo \\ ${ }^{2}$ Dosen Pendidikan Matematika FKIP Universitas Halu Oleo; Co-author: abbey_unchb@yahoo.co.id \\ ${ }^{3}$ Dosen PGSD FKIP dan PPs Universitas Halu Oleo
}

\begin{abstract}
Abstrak: Penelitian ini bertujuan untuk melihat pengaruh model Problem Based Learning terhadap peningkatan kemampuan komunikasi matematik siswa SMP. Populasi dalam penelitian ini adalah seluruh siswa kelas VIII SMP Negeri 5 Kendari yang terdiri dari sepuluh kelas parallel. Teknik pengambilan sampel menggunakan teknik purposive sampling. Teknik pengumpulan data dalam penelitian ini dilakukan dengan pemberian instrumen penelitian berupa lembar observasi dan istrumen tes kemampuan komunikasi matematik berbentuk tes uraian. Teknik analisis data menggunakan analisis deskriptif dan analisis inferensial. Berdasarkan hasil analisis data diperoleh kesimpulan bahwa model Problem Based Learning (PBL) memberikan pengaruh yang signifikan terhadap kemampuan komunikasi matematik siswa pada kedua kelas eksperimen. Hal ini ditunjukkan dengan nilai rata-rata pretest kemampuan komunikasi matematik siswa lebih rendah daripada nilai rata-rata posttest kemampuan komunikasi matematik siswa pada kedua kelas eksperimen.
\end{abstract}

Kata kunci: Model Pembelajaran Problem Based Learning (PBL), Kemampuan Komunikasi Matematik Siswa.

\begin{abstract}
This study aims to see the effect of Problem Based Learning model to improve the mathematic communication ability of secondary school students. The population in this study is all students of grade VIII of SMP Negeri 5 Kendari consisting of ten parallel classes. Sampling technique in this research using purposive sampling technique. Technique of data collection is done by giving theresearch instrument in the form of observation sheet and instrumen of test of mathematic communication ability in the form of description test. Data analysis techniques use descriptive analysis and inferential analysis. Based on the results of data analysis obtained the conclusion that the model of Problem Based Learning gives a significant effect on students mathematic communication skills in both of two classes. This is indicated by the average pretest value of the students mathematic communication which is lower than the posttest average of students' mathematic communication ability in the two experimental classes.
\end{abstract}

Keywords: Problem Based Learning (PBL) Learning Model, Ability of Mathematic Communication Students.

\section{PENDAHULUAN}

Komunikasi matematik pada kurikulum matematika di Indonesia menjadi salah satu standar kompentensi lulusan siswa sekolah dari pendidikan dasar sampai menengah. Hal ini tertuang dalam Peraturan Menteri Pendidikan dan Kebudayaan Nomor 22 Tahun 2006 tentang Standar Kompetensi lulusan dalam bidang matematika yang antara lain sebagai berikut: (1) Memahami konsep matematika, menjelaskan keterkaitan antarkonsep dan mengaplikasikan konsep atau logaritma secara luwes, akurat, efisien, dan tepat dalam pemecahan masalah, (2) Memecahkan masalah yang meliputi kemampuan memahami masalah, merancang model matematika, menyelesaikan model, dan menafsirkan solusi yang diperoleh, Mengkomunikasikan gagasan dengan simbol, tabel, diagram, atau media lain (Johar, dkk, 2017: 80). Kemampuan siswa untuk mengkomunikasikan gagasan dengan simbol, tabel, diagram, grafik, atau 
gambar merupakan kemampuan dasar komunikasi matematika.

Studi yang dilakukan TIMSS (International Mathematics and Science Study) mengungkapkan bahwa siswa Indonesia lemah dalam menyelesaikan soal-soal yang berkaitan dengan klastifikasi atau pembuktian, pemecahan masalah yang memerlukan penalaran matematika, menemukan generalisasi atau konjektur, dan menemukan hubungan antara data-data atau fakta yang diberikan. Sedang Studi PISA, siswa Indonesia lemah dalam menyelesaikan soal-soal yang difokuskan pada mathematics literacy yang ditunjukkan oleh kemampuan siswa dalam menggunakan matematika yang mereka pelajari untuk menyelesaikan persoalan dalam kehidupan sehari-hari (Amalia, dkk, 2015: 39).

Imelda dalam Johar, dkk (2017: 81) menyatakan bahwa kemampuan siswa Indonesia dalam komunikasi matematika sangat jauh di bawah negara-negara lain, sebagai contoh, untuk permasalahan matematik yang menyangkut kemampuan komunikasi matematik, siswa Indonesia yang berhasil menjawab benar hanya 5\% dan jauh di bawah negara seperti Siangpura, Korea, dan Taiwan yang mencapai lebih dari 50\%.

Atas dasar permasalahan di atas, maka kemampuan komunikasi matematik siswa harus ditingkatkan. Salah satu model yang dijadikan alternatif solusi pada penelitian ini adalah model pembelajaran Problem Based Learning (PBL). PBL merupakan suatu model pembelajaran yang menjadikan masalah sebagai titik awal dalam memulai pembelajaran dan dirancang sebagai pembelajaran yang menuntut siswa untuk memperoleh kemampuan menyelesaikan masalah, kemandirian dan memiliki skill partisipasi yang baik guna mendapatkan suatu pengetahuan baru (Nurbaiti, dkk, 2016: 1004). Pembelajaran dengan model PBL juga merupakan salah satu model pembelajaran inovatif yang dapat memberikan kondisi belajar aktif kepada siswa.

Problem Based Learning (PBL) merupakan pembelajaran yang penyampaiannya dilakukan dengan cara penyajian suatu permasalahan, mengajukan pertanyaan-pertanyaan, memfasilitasi penyelidikan, dan membuka dialog (Sani, 2014: 127). Model pembelajaran PBL merupakan pembelajaran dengan menghadapkan siswa pada permasalahan-permasalahan praktis sebagai pijakan dalam belajar.

Dewasa ini, model pembelajaran PBL mulai banyak digunakan sebab ditinjau secara umum, pembelajaran berdasarkan masalah terdiri dari menyajikan kepada siswa situasi masalah yang autentik dan bermakna yang dapat menberikan kemudahan kepada mereka dalam menyelesaikan masalah. Trianto (2009: 91) menyatakan belajar berdasarkan masalah adalah interaksi antara stimulus dan respon, merupakan hubungan antara dua arah belajar dan lingkungan. Lingkungan memberikan masukan pada siswa berupa bantuan dan masalah, sedangkan sistem saraf otak berfungsi menafsirkan bantuan itu secara efektif sehingga masalah yang dihadapi dapat diselidiki, dinilai, dianalisis serta dicari pemecahannya dengan baik.

Pada dasarnya model pembelajaran PBL diawali dengan aktivitas peseta didik untuk menyelesaikan masalah nyata yang ditentukan atau disepakati. Proses penyelesaian masalah tersebut berimplikasi pada terbentuknya peserta didik menyelesaikan masalah dan berpikir kritis serta sekaligus membentuk pengetahuan baru (Fathurrohman, 2015: 116).

Komunikasi matematik merupakan kemampuan untuk menyampaikan informasi, menerima, menghubungkan informasi yang berasal dari simbol, diagram, dan data kepada orang lain yang 
diterimanya. Menurut Maulana (Respati, 2016: 174) indikator kemampuan komunikasi matematik adalah: (1) Menghubungkan benda-benda nyata, gambar, dan diagram ke dalam ide atau model matematika, (2) Membuat model situasi atau masalah matematika kedalam bentuk gambar, tabel, grafik dan aljabar, (3) Menyatakan peristiwa sehari-hari kedalam bahasa dan simbol matematika, (4) Membaca dengan pemahaman suatu

\section{METODE PENELITIAN}

Penelitian ini dilaksanakan di SMP Negeri 5 Kendari. Waktu pelaksanaannya pada semester genap bulan JanuariFebruari tahun 2018. Populasi dalam penelitian ini adalah seluruh siswa kelas VIII di SMP Negeri 5 Kendari yang terdaftar pada tahun ajaran 2017/2018 yang tersebar pada sepuluh kelas. Pengambilan sampel pada penelitian ini dilakukan secara Purposive Sampling dengan pertimbangan mengambil dua kelas yang memiliki nilai rata-rata hasil UTS berbeda, yaitu kelas dengan nilai rata-rata tinggi $\left(\mathrm{VIII}_{\mathrm{C}}\right)$ dan kelas dengan nilai rata-rata rendah $\left(\mathrm{VIII}_{\mathrm{F}}\right)$. Kedua kelas dijadikan kelas eksperimen yang diajar dengan model PBL.

Penelitian ini menggunakan desain penelitian One-Group Pretest-Posttest Design. Desain ini dapat digambarkan sebagai berikut:

$$
\mathrm{O}_{1} \quad \mathrm{X} \quad \mathrm{O}_{2}
$$

(Sugiyono, 2016: 75)

Keterangan:

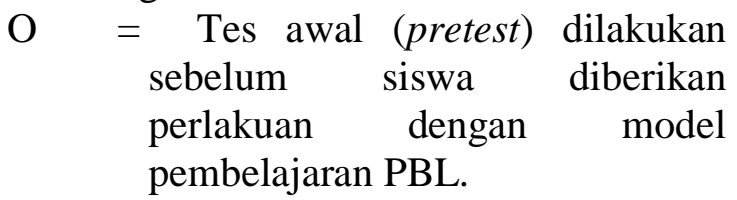

\section{HASIL PENELITIAN}

Kualitas pelaksanaan pembelajaran berdasarkan hasil observasi terhadap pelaksanaan pembelajaran matematika dengan menggunakan model pembelajaran presentasi matematika tertulis, (5) Membuat konjektur, menyusun argumen, merumuskan definisi, dan generalisasi, (6) Menjelaskan atau membuat pertanyaan atau cerita tentang matematika yang telah dipelajari. Keterlaksanaan proses pembelajaran dengan adanya indikator kemampuan komunikasi matematik di harapkan kemampuan komunikasi matematik siswa dapat berkembang.

$$
\begin{array}{rlr}
\mathrm{X}= & \begin{array}{l}
\text { Perlakuan (Treatment) } \\
\text { pembelajaran } \\
\text { menggunakan }
\end{array} & \begin{array}{r}
\text { berupa } \\
\text { dengan } \\
\text { model }
\end{array} \\
& \text { pembelajaran PBL. } \\
\mathrm{O}_{2}= & \text { Tes akhir (posttest) dilakukan } \\
& \text { setelah siswa diberikan dengan } \\
& \text { model pembelajaran Problem Based } \\
& \text { Learning (PBL). }
\end{array}
$$

Instrumen yang digunakan pada penelitian ini adalah lembar observasi dan tes kemampuan matematik siswa. Uji validitas instrumen tes kemampuan komunikasi matematik pada penelitian ini menggunakan validitas konstruksi dan validitas empiris.

Adapun pemberian skor kemampuan komunikasi matematik menggunakan pedoman penskoran Maryland Math Communication Rubric yang dikeluarkan oleh Maryland State Department of Education (1991) berupa holistic scale. Analisis yang digunakan untuk menguji hipotesis penelitian ini menggunakan uji-t data berpasangan (Paired Sample t-test). Namun, sebelum pengujian hipotesis dilakukan, terlebih dahulu melalui tahapan uji prasyarat, yaitu uji normalitas data penelitian.

PBL oleh guru di kelas VIII $_{C}$ pada materi Lingkaran, keberhasilan pengelolaan pembelajaran pada pertemuan pertama sangat baik dengan tingkat keberhasilan 
sebesar $84 \%$. Pelaksanaan pembelajaran pada pertemuan kedua dan ketiga mengalami peningkatan dibanding pertemuan pertama. Tingkat keberhasilan secara berturut-turut mencapai $88 \%$ dan $92 \%$.

Tingkat keberhasilan pelaksanaan pembelajaran pada pertemuan keempat dan kelima sama dengan tingkat keberhasilan pada pertemuan ketiga (tidak mengalami peningkatan) yaitu $92 \%$. Berdasarkan data ini, aktivitas guru untuk kelas VIII $_{C}$ yang diajar dengan model pembelajaran $\mathrm{PBL}$ terinterpretasi sangat baik dengan rata-rata keaktifan mencapai $89,6 \%$.

Berdasarkan hasil observasi aktivitas siswa dalam pelaksanaan pembelajaran matematika menggunakan model pembelajaran PBL di kelas $\mathrm{VIII}_{\mathrm{C}}$ pada materi Lingkaran. Pada pertemuan pertama persentase keaktifan siswa berdasarkan lembar observasi adalah $53,6 \%$. Pertemuan kedua, ketiga, keempat dan kelima ketercapaian aspek yang diamati berturut-turut mencapai $72 \%$, $80,8 \%, 89,6 \%$ dan $92,8 \%$. Secara umum, ketercapaian keseluruhan aspek yang diamati pada pertemuan kedua, ketiga, keempat dan kelima mengalami peningkatan dibandingkan pertemuan pertama. Ketercapaian pertemu. Beradasarkan data ini, dapat disimpulkan bahwa ditinjau dari tingkat keaktifan siswa yang diajar dengan model pembelajaran PBL terinterpretasi baik dengan rata-rata keaktifan mencapai $77,76 \%$.

Deskripsi kemampuan komunikasi matematik berdasarkan hasil analisis deskriptif diperoleh nilai rata-rata Pretest kemampuan komunikasi matematik siswa sebelum diajar dengan model pembelajaran PBL di kelas VIII $_{\mathrm{C}}$ sebesar 60,25, sedangkan nilai rata-rata Posttest kemampuan komunikasi matematik siswa setelah diajar dengan model pembelajarana PBL sebesar sebesar 83,25.

Distribusi nilai kemampuan komunikasi matematik siswa kelas VIII $_{\mathrm{C}}$ dapat dilihat pada Gambar 1.

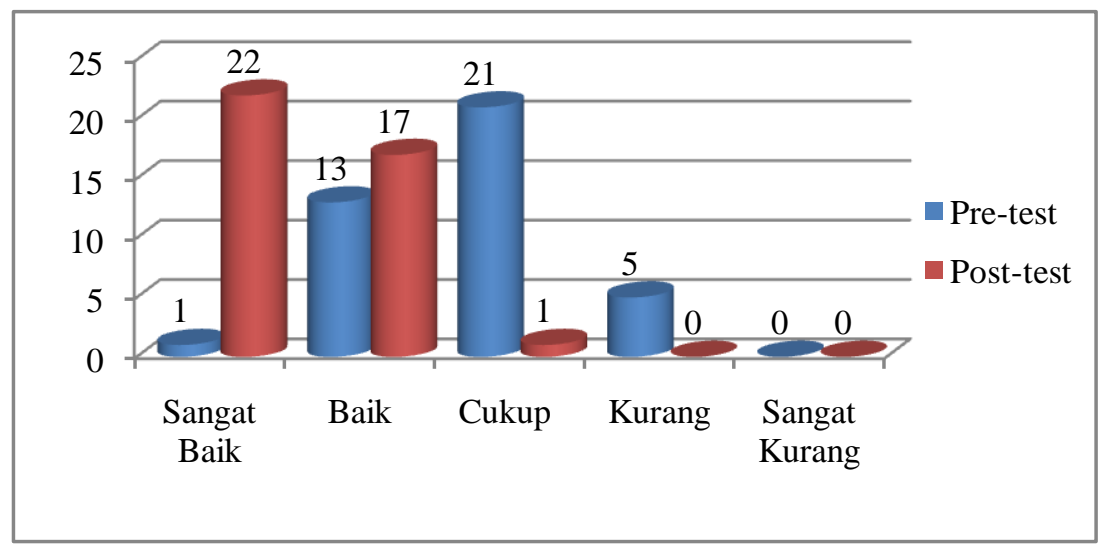

\section{Gambar 1. Diagram Data Nilai Kemampuan Komunikasi Matematik Siswa Kelas VIII $_{C}$}

Gambar 1. menunjukkan bahwa kemampuan komunikasi matematik siswa lebih baik setelah diajar dengan model pembelajaran PBL dibandingkan dengan sebelum diajar dengan model pembelajaran PBL.

Berdasarkan hasil analisis deskriptif diperoleh nilai rata-rata Pretest kemampuan komunikasi matematik siswa sebelum diajar dengan model pembelajaran PBL di kelas VIII $_{F}$ sebesar 51,35, sedangkan nilai rata-rata Posttest kemampuan komunikasi matematik siswa setelah diajar dengan model pembelajarana PBL sebesar sebesar 85,14. Median (nilai tengah) pada Pretest diperoleh 55,00 dan pada posstest diperoleh 85,00. Modus (nilai yang sering 
muncul) pada Pretest diperoleh 55 dan pada posstest diperoleh 95. Nilai ini menunjukkan bahwa sebagian besar siswa memiliki tingkat kemampuan komunikasi matematik yang tergolong cukup pada Pretest dan tergolong sangat baik pada posstest. Nilai minimum kemampuan komunikasi matematik siswa pada saat Pretest adalah sebesar 5 dan nilai maksimumnya sebesar 80. Sedangkan nilai minimum pada saat Posttest adalah sebesar 60 dan nilai maksimumnya adalah sebesar 100. Adapun Standar deviasi (simpangan baku) dan varians pada Pretest diperoleh 12,34 dan 152,29 serta pada posstest diperoleh 11,27 dan 127,07. Nilai varians dari kedua data tersebut menunjukkan bahwa kemampuan komunikasi matematik siswa kelas $\mathrm{VIII}_{\mathrm{F}}$ sebelum pembelajaran lebih beragam daripada setelah pembelajaran dengan model pembelajaran PBL

Adapun distribusi nilai kemampuan komunikasi matematik siswa kelas VIII $_{F}$ dapat dilihat pada Gambar 1.

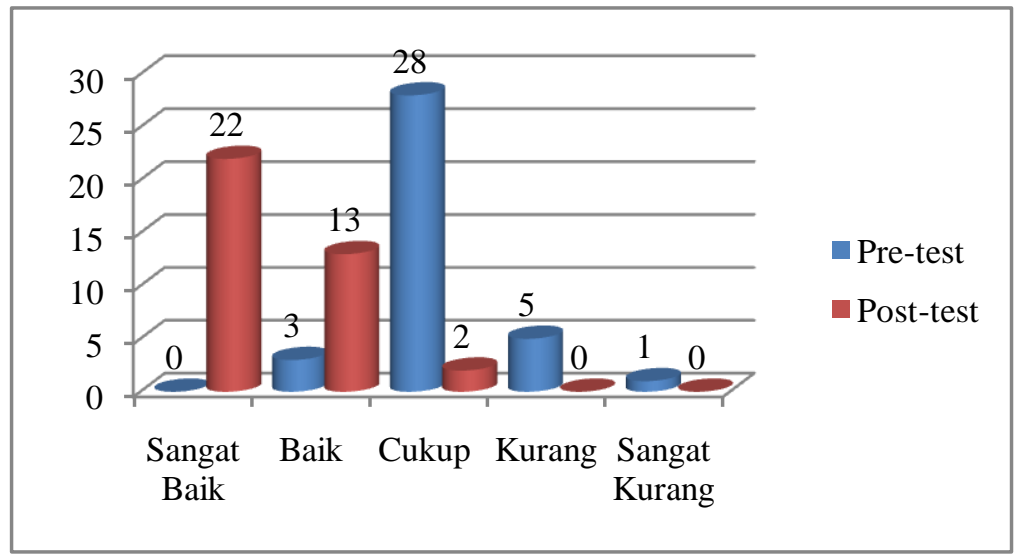

\section{Gambar 2. Diagram Data Nilai Kemampuan Komunikasi Matematik Siswa Kelas VII $_{F}$}

Gambar 2. menunjukkan bahwa kemampuan komunikasi matematik siswa lebih baik setelah diajar dengan model pembelajaran PBL dibandingkan dengan sebelum diajar dengan model pembelajaran PBL.

Distribusi skor $N \_$Gain kelas VIII $_{C}$ dan kelas $\mathrm{VIII}_{\mathrm{F}}$ merupakan distribusi peningkatan kemampuan komunikasi matematik yang dialami siswa setelah adanya perlakuan dengan model pembelajaran PBL diperoleh bahwa secara klasikal peningkatan kemampuan komunikasi matematik siswa kelas VIII $_{\mathrm{C}}$ dan siswa kelas VIII $_{\mathrm{F}}$ yang diajar dengan model pembelajaran PBL tergolong sedang dan tinggi karena 35 orang siswa atau $87,5 \%$ siswa pada kelas VIII $_{C}$ dan 35 orang siswa atau 94,6\% siswa pada kelas $\mathrm{VIII}_{\mathrm{F}}$ memperoleh peningkatan ( $N \_$Gain) sedang dan tinggi. Hal ini menunjukkan bahwa, secara klasikal peningkatan kemampuan komunikasi matematik siswa kelas VIII $_{F}$ lebih baik daripada kelas VIII $_{\mathrm{C}}$ yang diajar dengan model pembelajaran PBL.

Berdasarkan hasil analisis deskriptif diperoleh nilai rata-rata $N \_$Gain Kelas VIII $_{C}$ adalah 0,58 yang berada pada kategori sedang dan rata-rata $N_{-}$Gain Kelas VIII $_{\mathrm{F}}$ adalah 0,69 yang berada pada kategori sedang. Median (nilai tengah) pada siswa kelas VIII $_{C}$ adalah 0,55 dan siswa kelas VIII $_{\mathrm{F}}$ adalah 0,75 . Modus (nilai yang sering muncul) pada siswa kelas VIII $_{C}$ adalah 1,00 dan siswa kelas $\mathrm{VIII}_{\mathrm{F}}$ adalah 1,00. Nilai ini menunjukkan bahwa sebagian besar siswa kelas VIII $_{C}$ dan siswa kelas VIII $_{F}$ memiliki peningkatan kemampuan komunikasi 
matematik yang tergolong tinggi. Nilai minimum siswa kelas VIII $_{C}$ adalah 0,14 dan siswa kelas $\mathrm{VIII}_{\mathrm{F}}$ adalah 0,00 . Sedangkan nilai maksimum siswa kelas VIII $_{C}$ adalah 1,00 dan siswa kelas VIII $_{F}$ adalah 1,00. Adapun Standar deviasi (simpangan baku) dan varians pada kelas VIII $_{C}$ adalah 0,26 dan 0,07 serta pada siswa kelas $\mathrm{VIII}_{\mathrm{F}}$ diperoleh 0,24 dan 0,06. Nilai varians dari kedua kelas tersebut menunjukkan bahwa tingkat keragaman peningkatan kemampuan komunikasi matematik siswa homogen.

Uji normalitas data merupakan salah satu prasyarat untuk melakukan uji hipotesis yang dimaksudkan untuk mengetahui apakah data berasal dari populasi yang berdistribusi normal atau tidak. Untuk keperluan ini maka statistik yang digunakan adalah uji KolmogorovSmirnov menggunakan bantuan program SPSS 21 pada data Pretest dan Posttes pada kedua kelas eksperimen.. Berdasarkan hasil perhitungan SPSS 21 dilihat bahwa nilai Asymp. Sig. (2-tailed) pada kelas VIII $_{\mathrm{C}}$ untuk Pretest adalah $0,270>\alpha$ (dengan $\alpha=0,05$ ), sehingga $\mathrm{H}_{0}$ diterima. Karena $\mathrm{H}_{0}$ diterima maka dapat disimpulkan bahwa data kemampuan komunikasi matematik siswa $\mathrm{VIII}_{\mathrm{C}}$ untuk Pretest berdistribusi normal.

Selanjutnya, nilai Asymp. Sig. (2tailed) untuk Posttest adalah 0,692> $>$ (dengan $\alpha=0,05$ ), sehingga $\mathrm{H}_{0}$ diterima. Karean $\mathrm{H}_{0}$ diterima maka dapat disimpulkan bahwa data kemampuan komunikasi matematik siswa kelas VIII $_{\mathrm{C}}$ untuk Posttest berdistribusi normal. Pada kelas VIII $_{\mathrm{F}}$, terlihat bahwa nilai Asymp. Sig. (2-tailed) untuk Pretest adalah 0,154 $>\alpha$ (dengan $\alpha=0,05)$, sehingga $\mathrm{H}_{0}$ diterima. Karena $\mathrm{H}_{0}$ diterima maka dapat disimpulkan bahwa data kemampuan komunikasi matematik siswa $\mathrm{VIII}_{\mathrm{F}}$ untuk Pretest juga berdistribusi normal. Selanjutnya, nilai Asymp. Sig. (2-tailed) untuk Posttest adalah 0,296> $\alpha$ (dengan $\alpha$ $=0,05)$, sehingga $\mathrm{H}_{0}$ diterima. Karean $\mathrm{H}_{0}$ diterima maka dapat disimpulkan bahwa data kemampuan komunikasi matematik siswa kelas $\mathrm{VIII}_{\mathrm{F}}$ untuk Posttest juga berdistribusi normal.

Data yang diperoleh seluruhnya berdistribusi normal, maka untuk menguji pengaruh model pembelajaran PBL terhadap kemampuan komunikasi matematik siswa digunakan uji statistik parametrik yaitu uji-t berpasangan (paired samples t-test). Rumus hipotesis yang diuji yaitu :

$$
\begin{aligned}
& \mathrm{H}_{0}: \mu_{2}-\mu_{1}=0 \quad \text { lawan } \\
& \mathrm{H}_{1}: \mu_{2}-\mu_{1}>0
\end{aligned}
$$

Keterangan:

$\mu_{2}=$ Rata-rata post-test kemampuan komunikasi matematik siswa

$\mu_{1}=$ Rata-rata pre-test kemampuan komunikasi matematik siswa Hipotesis yang diajukan:

$\mathrm{H}_{0}=$ Tidak terdapat pengaruh yang signifikan model pembelajaran Problem Based Learning (PBL) terhadap kemampuan komunikasi matematik siswa.

$\mathrm{H}_{1}=$ Terdapat pengaruh yang signifikan model pembelajaran Problem Based Learning (PBL) terhadap kemampuan komunikasi matematik siswa.

Tabel 1. Hasil uji paired samples test kemampuan komunikasi matematik siswa kelas VIIIC

\begin{tabular}{cccccccc}
\hline \multicolumn{7}{c}{ Perbedaan Berpasangan } \\
& $\begin{array}{c}\text { Rata- } \\
\text { rata }\end{array}$ & $\begin{array}{c}\text { Standar } \\
\text { Deviasi }\end{array}$ & $\begin{array}{c}\text { Kesalahan } \\
\text { Rata-rata }\end{array}$ & $\boldsymbol{t}$ & df & $\begin{array}{c}\text { Sig. }(2- \\
\text { tailed) }\end{array}$ \\
\hline Pasangan 1 & 23.000 & 11.424 & 1.806 & 12.733 & 39 & \\
\hline
\end{tabular}

Pengaruh Model Pembelajaran Problem Based Learning (PBL) Terhadap Kemampuan Komunikasi Matematik Siswa SMP (Hafely, Anwar Bey, La Ode Ahmad Jazuli, Nana Sumarna) 


\begin{tabular}{ll}
\hline Posttest - Pretest & \multicolumn{1}{c}{.000} \\
\hline Berdasarkan tabel 1. terlihat bahwa & pembelajaran Problem Based Learning \\
nilai Asymp. Sig. (2-tailed) adalah 0,000 & (PBL) terhadap kemampuan komunikasi \\
$\alpha(\alpha=0,05)$, sehingga $\mathrm{H}_{0}$ ditolak. Oleh & matematik siswa kelas VIII SMP Negeri 5 \\
karena itu dapat disimpulkan bahwa & Kendari.
\end{tabular}
terdapat pengaruh yang signifikan model

Tabel 2. Hasil uji paired samples test kemampuan komunikasi matematik siswa kelas VIII $_{F}$

\begin{tabular}{lccccccr}
\hline & \multicolumn{3}{c}{ Perbedaan Berpasangan } & & & \\
\cline { 2 - 5 } & $\begin{array}{c}\text { Rata- } \\
\text { rata }\end{array}$ & $\begin{array}{c}\text { Standar } \\
\text { Deviasi }\end{array}$ & $\begin{array}{c}\text { Standar } \\
\text { Kesalahan } \\
\text { Rata-rata }\end{array}$ & $\boldsymbol{t}$ & $\boldsymbol{d}$ f & $\begin{array}{c}\text { Sig. (2- } \\
\text { tailed) }\end{array}$ \\
\hline Pasangan 1 & & & & & & \\
Posttest - Pretest & 33.784 & 14.113 & 2.320 & 14.561 & 36 & .000 \\
\hline
\end{tabular}

Berdasarkan tabel 4.14 terlihat bahwa nilai Asymp. Sig. (2-tailed) adalah $0,000<\alpha(\alpha=0,05)$, sehingga $\mathrm{H}_{0}$ ditolak. Oleh karena itu dapat disimpulkan bahwa terdapat pengaruh yang signifikan model

\section{PEMBAHASAN}

Berdasarkan telaah terhadap pelaksanaan dan hasil proses pembelajaran matematika di SMP Negeri 5 Kendari, salah satu penyebab sulitnya mengembangkan kemampuan komunikasi matematik dalam mata pelajaran matematika adalah saat siswa dihadapkan pada suatu masalah matematika. Dimana, sebagian besar siswa hanya sekedar menghafal konsep sehingga siswa belum mampu mengidentifikasikan informasiinformasi yang terdapat pada suatu masalah matematika tersebut. Akibatnya, saat dihadapkan pada suatu masalah matematika yang membutuhkan pemahaman, siswa tersebut mengalami kesulitan. Oleh karena itu, diperlukan perhatian dalam proses pembelajaran matematika terutama untuk kesesuaian model pembelajaran yang digunakan dengan materi yang diajarkan. Model pembelajaran yang menekankan siswa terlibat aktif salah satunya adalah model pembelajaran PBL. pembelajaran Problem Based Learning (PBL) terhadap kemampuan komunikasi matematik siswa kelas VIII SMP Negeri 5 Kendari.

Pelaksanaan pelitian ini menggunakan dua kelas eksperimen yaitu kelas VIIIC $\neg$ dan kelas VIIIF yang diajar menggunakan model pembelajaran PBL. Pada kedua kelas tersebut, siswa diberi Pretest sebelum diterapkan model pembelajaran PBL kemudian diberi Posttest perlakuan. Total pertemuan dalam penelitian ini yakni sebanyak tujuh kali pertemuan dengan lima kali pertemuan digunakan untuk proses pembelajaran dan dua kali pertemuan digunakan untuk pelaksanaan Pretest dan Posttest kemampuan komunikasi matematik siswa.

Pembelajaran yang dilaksanakan dengan model pembelajaran PBL memiliki lima tahap dalam pelaksanaannya yaitu orientasi siswa pada masalah, mengorganisasi siswa untuk belajar, membimbing penyelidikan kelompok atau individu, menyajikan hasil karya, serta menganalisis dan mengevaluasi pemecahan masalah. Rangkaian tahaptahap dalam pembelajaran ini sangat menekankan kepada siswa agar mampu 
menyelesaikan suatu masalah dengan idenya sendiri, sehingga materi pelajaran dapat mudah diingat oleh siswa dan tidak mudah dilupakan serta dapat melatih dan meningkatkan kemampuan komunikasi matematik siswa dalam memecahkan masalah matematika.

Pelaksanaan perlakuan pada pertemuan pertama mengalami sedikit hambatan. Siswa membutuhkan waktu untuk menyesuaikan diri dengan model pembelajaran yang baru diterapkan pada kedua kelas eksperimen, terutama pada saat pembentukan kelompok, sehingga proses ini cukup menyita waktu pembelajaran. Siswa yang tidak terbiasa dengan pembentukan kelompok belajar terutama teman kelompoknya, awalnya kurang antusias dalam proses pembelajaran ini. Beberapa siswa menunjukan sikap yang kurang bekerjasama dalam kelompok, sehingga hanya sedikit siswa yang aktif dalam kelompok belajar pada saat proses pembelajaran berlangsung. Hal ini mengakibatkan proses penyerapan materi pembelajaran oleh siswa kurang maksimal. Perlahan-lahan, hambatan-hambatan yang terjadi dapat diatasi dan diminimalisir. Guru dapat mengontrol dan mengarahkan siswa dengan baik, sehingga antusias bekerjasama dalam kelompoknya.

Pada pertemuan kedua dan pertemuan-pertemuan berikutnya, proses pembelajaran berjalan dengan baik dan lancar. Siswa juga lebih memahami setiap tahap dalam model pembelajaran PBL yang diterapkan di kelas. Siswa telah menunjukan sikap antusias dalam pembelajaran dan mulai merasa bertanggung jawab dalam menyelesaikan masalah pada LKS yang diberikan. Seiring dengan hal tersebut, pemahaman siswa terhadap materi juga meningkat. Siswa yang tadinya membutuhkan pengarahan guru dalam memberikan kesimpulan juga telah mampu memberikan kesimpulan secara mandiri. Disimpulkan bahwa siswa memerlukan waktu untuk beradaptasi terhadap suatu pembelajaran yang baru diterapkan dalam kelas. Hal ini didukung dengan persentase ketercapaian aspek yang diamati yang secara keseluruhan meningkat dari tiap pertemuan.

Data kemampuan komunikasi matematik siswa diperoleh melalui tes kemampuan komunikasi matematik siswa. Sebelum siswa diberikan perlakuan yaitu berupa model pembelajaran PBL, diberikan tes yang terkait salah satu materi yang telah dipelajari yaitu Sistem Persamaan Linear Dua Variabel (SPLDV). Sedangkan tes yang diberikan setelah adanya perlakuan yaitu tes pada materi Lingkaran.

Berdasarkan hasil analisis deskriptif dari data yang diperoleh melalui tes kemampuan komunikasi matematik siswa pada kelas VIIIC, pada tes awal (Pretest) diperoleh nilai rata-rata sebesar 60,25 sedangkan pada tes akhir (Posttest) diperoleh nilai rata-rata sebesar 83,25. Sedangkan untuk kelas VIIIF, pada tes awal (Pretest) diperoleh nilai rata-rata sebesar 51,35 sedangkan pada tes akhir (Posttest) diperoleh nilai rata-rata sebesar 85,14 . Hal ini menunjukkan bahwa kemampuan komunikasi matematik siswa setelah diajar dengan model pembelajaran PBL lebih baik daripada sebelum diajar dengan model pembelajaran PBL pada kedua kelas eksperimen. Berdasarkan keragaman data (varians), pada Posttest mengalami penurunan dibandingkan pada Pretest pada kedua kelas eksperimen. Nilai varians pada Posttest kemampuan komunikasi matematik yang lebih kecil dibandingkan varians pada Pretest dari kedua data tersebut menunjukkan bahwa kemampuan komunikasi matematik siswa sebelum pembelajaran lebih beragam daripada setelah pembelajaran.

Distribusi nilai kemampuan komunikasi matematik siswa pada kelas VIIIC untuk Pretest berada pada kategori kurang, cukup, baik dan sangat baik. 
Dimana 5 siswa $(12,5 \%)$ berada pada kategori kurang, 21 siswa $(52,5 \%)$ berada pada kategori cukup, 13 siswa $(32,5 \%)$ berada pada kategori baik dan 1 siswa $(2,5 \%)$ berada pada kategori sangat baik terhadap materi pembelajaran. Sedangkan distribusi nilai kemampuan komunikasi matematik siswa untuk Posttest barada pada kategori cukup, baik dan sangat baik. Dimana 1 siswa $(2,5 \%)$ berada pada kategori cukup, 17 siswa $(42,5 \%)$ berada pada kategori baik dan 22 siswa $(55 \%)$ siswa berada pada kategori sangat baik. Pada distribusi nilai kemampuan komunikasi matematik siswa pada kelas VIIIF untuk Pretest berada pada kategori sangat kurang, kurang, cukup dan baik. Dimana 1 siswa $(2,7 \%)$ berada pada kategori sangat kurang, 5 siswa $(13,51 \%)$ berada pada kategori kurang, 28 siswa $(75,68 \%)$ berada pada kategori cukup dan 3 siswa $(8,11 \%)$ berada pada kategori baik terhadap materi pembelajaran. Sedangkan distribusi nilai kemampuan komunikasi matematik siswa untuk Posttest barada pada kategori cukup, baik dan sangat baik. Dimana 2 siswa $(5,4 \%)$ berada pada kategori cukup, 13 siswa $(35,14 \%)$ berada pada kategori baik dan 22 siswa $(59,46 \%)$ siswa berada pada kategori sangat baik terhadap materi pembelajaran.

Peningkatan

kemampuan

komunikasi matematik siswa setelah pembelajaran dengan model PBL juga ditunjukan oleh nilai rata-rata N_Gain. Dimana, secara keseluruhan siswa pada kedua kelas eksperimen mengalami peningkatan kemampuan komunikasi matematik. Hal ini sejalan dengan pendapat Putra (Alzianina, 2016: 13) yang mengungkapkan bahwa salah satu kelebihan model Problem Based Learning ialah dapat merangsang perkembangan kemampuan siswa, karena siswa terlibat secara aktif untuk mendapatkan pengetahuan yang dibutuhkan, sehingga akan membantu meningkatkan kemampuan siswa.

Berdasarkan uraian hasil analisis deskriptif di atas, pada tes awal (pretest) diperoleh nilai rata-rata yang lebih rendah daripada nilai rata-rata yang diperoleh pada tes akhir (posttest) pada kedua kelas eksperimen. Hal ini menunjukkan bahwa model pembelajaran PBL lebih berpengaruh dalam meningkatkan kemampuan komunikasi matematik siswa di kelas VIIIf dibanding kelas VIIIC.

Pengujian hipotesis dalam penelitian ini menggunakan uji 2-Related Sample Test yaitu uji-t berpasangan (paired samples t-test), dengan terlebih dahulu melewati uji normalitas terhadap data pretest dan posttest pada kedua kelas eksperimen. Berdasarkan uji normalitas data dengan menggunakan uji Kolmogorov-Smirnov diperoleh kemampuan komunikasi matematik siswa pada data pretest dan posttest untuk kedua kelas eksperimen berdistribusi normal. Sehingga untuk pengujian hipotesis dilakukan dengan menggunakan statistik parametrik.

Berdasarkan hasil uji hipotesis untuk melihat pengaruh model pembelajaran PBL terhadap kemampuan komunikasi matematik siswa pada kedua kelas eksperimen, terlihat bahwa terdapat pengaruh yang signifikan model pembelajaran PBL terhadap kemampuan komunikasi matematik siswa. Hal ini didasarkan pada nilai signifinkansi uji-t berpasangan (paired samples t-test) yang lebih kecil dari $\propto=0,05$ sehingga $\mathrm{H} 0$ ditolak. Dengan demikian, diperoleh hasil pengujian hipotesis yang menyatakan bahwa terdapat pengaruh yang signifikan model pembelajaran Problem Based Learning (PBL) terhadap kemampuan komunikasi matematik siswa. 


\section{KESIMPULAN DAN SARAN}

Berdasarkan hasil penelitian dan pembahasan, maka dapat ditarik kesimpulan sebagai berikut.

1. Proses pembelajaran matematika dengan model pembelajaran PBL pada siswa kelas VIII SMP Negeri 5 Kendari tergolong sangat baik pada keterlaksanaan pembelajaran oleh guru dan tergolong baik pada aktivitas siswa dalam pembelajaran. Hal ini ditunjukkan dengan rata-rata persentase keterlaksanaan pembelajaran oleh guru pada 5 kali pertemuan yaitu sebesar $89,6 \%$ di kelas VIIIC dan 90,4\% di kelas VIIIF. Demikian pula dengan rata-rata persentase keaktifan siswa pada 5 kali pertemuan yaitu sebesar $77,76 \%$ di kelas VIIIC dan $72,8 \%$ di kelas VIIIF.

2. Kemampuan komunikasi matematik siswa sebelum diajar dengan model pembelajaran PBL pada kedua kedua kelas eksperimen memiliki nilai ratarata sebesar 60,25 nilai minimum yang diperoleh adalah 35 dan nilai maksimum yang diperoleh adalah 90, nilai modus dan median yang diperoleh 60 dan 60,00 serta standar deviasai (simpangan baku) dan varians yang diperoleh adalah 12,35 dan 152,50 pada kelas VIIIC. Sedangkan untuk kelas VIIIF memiliki nilai rata-rata sebesar 51,35 , dengan nilai minimum yang diperoleh adalah 5 dan nilai maksimum yang diperoleh adalah 80 , nilai modus dan median yang diperoleh 55 dan 55,00 serta standar deviasai (simpangan baku) dan varians yang diperoleh adalah 12,34 dan 152,29.

3. Kemampuan komunikasi matematik siswa setelah diajar dengan model pembelajaran PBL pada kedua kedua kelas eksperimen memiliki nilai ratarata sebesar 83,25 , nilai minimum yang diperoleh adalah 60 dan nilai maksimum yang diperoleh adalah 100, nilai modus dan median yang diperoleh 85 dan 85,00 serta standar deviasai (simpangan baku) dan varians yang diperoleh adalah 11,13 dan 123,78 pada kelas VIIIC. Sedangkan untuk kelas VIIIF memiliki nilai rata-rata sebesar 85,14 , dengan nilai minimum yang diperoleh adalah 60 dan nilai maksimum yang diperoleh adalah 100, nilai modus dan median yang diperoleh 95 dan 85,00 serta standar deviasai (simpangan baku) dan varians yang diperoleh adalah 11,27 dan 127,07.

4. Pembelajaran menggunakan model pembelajaran Problem Based Learning (PBL) memberikan pengaruh yang signifikan terhadap kemampuan komunikasi matematik siswa pada kedua kelas eksperimen. Hal ini didasarkan pada nilai signifikansi uji-t berpasangan (paired sampls t-test) yang lebih kecil dari 0,05

Berdasarkan hasil penelitian ini dapat disarankan beberapa hal sebagai berikut:

1. Kepada para guru yang mengajar mata pelajaran matematika sekiranya dapat menggunakan model pembelajaran Problem Based Learning (PBL) sebagai salah satu alternatif model pembelajaran untuk meningkatkan kemampuan komunikasi matematik siswa.

2. Hendaknya kemampuan komunikasi matematik siswa mendapat perhatian yang serius dari pihak guru untuk meningkatkan penguasaan matematika serta kemampuan memecahkan masalah yang dimiliki siswa.

3. Bagi peneliti yang ingin melakukan penelitian sejenis, langkah-langkah pembelajaran dengan model pembelajaran PBL sebaiknya dipahami secara maksimal, agar keterlaksanaan pembelajaran nantinya bisa maksimal. 


\section{DAFTAR PUSTAKA}

Alzianina, Aulia Eka. 2016. Pengaruh Model Problem Based Learning Terhadap Kemampuan Komunikasi Matematis Siswa (Studi Pada Siswa Kelas VIII Semester Genap Smp Negeri 14 Bandar Lampung Tahun Pelajaran 2015/2016). Skripsi pada Jurusan Pendidikan Matematika Universitas Lampung: tidak diterbitkan.

Amalia, Y., Duskri, M., dan Ahmad, A. 2015. Penerapan Model Eliciting Activities untuk Meningkatkan Kemampuan Berpikir Kreatif Matematis dan Self Confidence Siswa SMA. Jurnal Didaktik Matematika. 2(2): 38-48.

Fathurrohman, Muhammad. 2015. ModelModel Pembelajaran Inovatif. Yogyakarta: Ar-Ruzz Media.

Jihad, Asep dan Haris, Abdul. 2013. Evaluasi Pembelajaran. Yogyakarta: Multi Pressindo.

Johar, Rahmah, Diandita, Elly R., dan Abidin, Taufik F. 2017. Kemampuan Komunikasi Matematis dan Metakognitif Siswa SMP Pada Materi Llingkaran Berdasarkan Gender. Jurnal Pendidikan Matematika. 11(2): 7997.

Nurbaiti, Sri I., Irawati, Riana, dan Lichteria R. 2016. Pengaruh Pendekatan Problem Based Learning Terhadap Kemampuan Komunikasi Matematis dan Motivasi Belajar Siswa. Jurnal Pena Ilmiah. 1(1): 1001-1010.

Respati, Ressa, Gusrayani, Diah, dan Maulana. Pengaruh Pendekatan Problem Based Learning (PBL) Terhadap Kemampuan Pemahaman Matematis dan Komunikasi Matematis Siswa Pada Materi Skala dan Perbandingan. Jurnal Pena Ilmiah. 1(1) : 171-180.

Sani, Ridwan Abdullah. 2014. Pembelajaran Saintifik untuk Implementasi Kurikulum 2013. Jakarta: Bumi Aksara.

Sugiyono. 2015. Statistika untuk Penelitian. Bandung: Alfabeta. 2016. Metode Penelitian Kuantitatif, Kualitatif dan $R \& D$. Alfabeta: Bandung.

Trianto. 2009. Mendasain Model Pembelajaran Inovatif-Progresif. Surabaya: Kencana Prenada Media Group. 